\title{
Fotografia como arte do trauma e imagem-ação: jogo de espectros na fotografia de desaparecidos das ditaduras na América Latina
}

Photography as the art of trauma and image-action: light game in the photographs of missing people in Latin America dictatorships

\section{Márcio Seligmann-Silva}

Docente e pesquisador do Instituto de Estudos da Linguagem (IEL-Unicamp) E-mail:m.seligmann@uol.com.br

RESUMO

Ernst Simmel descreveu o trauma de guerra com uma fórmula que deixa clara a relação entre técnica, trauma, violência e o registro de imagens: "A luz do flash do terror cunha/estampa uma impressão fotograficamente exata". O trabalho analisa a relação entre fotografia e trauma no contexto das ditaduras da América Latina entre os anos 1960 e 1980. Pensa-se nas imagens na sua relação com a violência e sobre a nova era digital que favorece uma cultura da amnésia.

Palavras-chave: Fotografia e trauma; Imagens da violência; Imagens do desaparecimento
AbStRACT

Ernst Simmel described the trauma of war with a formula that clarifies the relationship among technique, trauma, violence and the recording of images. "The flash light of terror prints a photographically exact impression". This article shows the relation between photography and trauma in the context of the Latin American dictatorships in the years 1960-1980. It reflects on the images in its relation to violence as well as about our new digital era that favor a culture of amnesia.

Keywords: Photography and trauma; Images of violence; Images of missing people 
1 - Trabalho apresentado no encontro "Violence \& The Contexts of Hostility", organizado pela Inter-Disciplinary Net (Oxford), ocorrido em Budapeste entre os dias 4 e 7 de maio de 2009.

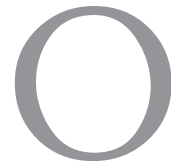
fim da foto analógica pode ser pensado como mais um momento de um processo em direção à digitalização de nosso universo "real". Matrix não seria, deste ponto de vista, nossa origem, mas, antes, o nosso fim. Parafraseando e deslocando o sentido de uma frase de Karl Kraus, cara a Walter Benjamin: "A origem é o fim." Esse processo inicia-se pelo campo mais passível de se digitalizar, mais "leve", ou seja, nosso universo comunicacional. [1]

Todas nossas bases de informação estão se digitalizando, portanto era de se esperar que logo esta passagem para a fotografia digital deveria ocorrer, assim como o livro, o jornal, nossas contas, recibos, cartas etc. estão também passando para o registro digital. No caso específico da fotografia, o que perdemos com esta passagem para o digital? Perdemos muitas coisas: antes de mais nada, o filme e todos os procedimentos mecânicos e químicos a ele vinculados, com destaque para a revelação. Esta implicava um espaçamento temporal entre o ato fotográfico e a possibilidade de se visualizar a imagem captada. O tempo da foto digital é vertiginoso, imediato, é um tempo sem-tempo. Ele capta, como a foto analógica, o aqui-e-agora, mas, diferentemente desta, apresenta imediatamente a imagem no visor digital da câmara. Por outro lado, esta imagem captada é apenas a base para futuros trabalhos de intervenção na imagem. Portanto. Ela, como veremos melhor, põe em questão a própria unidade espaço-temporal que está na origem da foto. Esta mudança de temporalidade reflete tanto um aceleramento generalizado da vida provocado pela virada digital (ela põe tudo em andamento, acelera as comunicações e transformações, abala tudo que se quer estático) como aponta para uma consequência desta aceleração: a dissolução das identidades e dos espaços.

O digital corresponde ao mundo em processo de liquefação, de quebra das identidades e das fronteiras. As fotos de identificação faziam parte da relação da foto analógica com o estágio de desenvolvimento das técnicas de controle social em uma sociedade que ainda atribuía uma certa estabilidade à identidade das imagens. As fotografias, não por acaso, acompanhavam nossa impressão digital na carteira de identidade. Este tipo de identificação está sendo substituído por outros meios, como 
a leitura de nosso corpo e de nossos códigos genéticos. Logo a carteira de identidade com a fotografia será dispensável.

Ocorre, portanto, um abalo nesta passagem da fotografia analógica para a digital. Um abalo na credibilidade das imagens. Estas deixam de atestar, de testemunhar, ou se o fazem, o testemunho ganha um novo caráter, mais performático, como acompanhamos no caso das fotos da prisão de Abu Graib. A onipresença dos dispositivos de captação transforma todo real em citacion à l'ordre du jour. A fotografia era pensada como índice capaz de designar e atestar uma singularidade física de um aqui e agora. Este aqui e agora foi abalado pela era das imagens eletrônicas. As imagens agora se tornam mais "maleáveis", manipuláveis. Não que a foto analógica não permitisse as manipulações, como cortes de personagens nas fotos e retoques, mas é evidente que a fotografia digital multiplica estas possibilidades de moldagem das imagens. $\mathrm{O}$ "isto ocorreu”, ou o "isto foi assim", da fotografia analógica, é posto em questão pela inscrição digitalizada. Os famosos fotogramas de Moholy-Nagy e de Man Ray (fotos obtidas sem uma câmera e com a simples sobreposição de objetos em superfícies sensíveis à luz) não podem servir mais de síntese do funcionamento da fotografia digital, como o serviam para pensarmos a foto analógica. Este abalo pode ser comparado àquele detectado por Benjamin em seu texto de 1936 sobre a obra e arte na era da sua reprodutibilidade técnica. Para aquele autor, vale lembrar, a fotografia significou um "violento abalo da tradição", ou seja a despedida de nossa relação com a tradição. A visão de mundo correspondente à teoria da fotografia de Benjamin já apresenta um universo cada vez mais achatado no seu próprio presente. Podemos dizer que a era digital potencializou ainda mais este mergulho no presente.

A fotografia, enquanto técnica, máquina de registrar o instante, arrancando-o da continuidade do tempo, congelando um momento com seu olhar de Medusa, pode ser aproximada da cena do trauma, tal como ela foi descrita por Freud em seu Para além do princípio do Prazer, e da cena do choque, como Benjamin o pensou em seu ensaio Sobre alguns temas em Baudelaire. Ernst Simmel, autor de Kriegsneurosen und psychisches Trauma (1918), descreveu o trauma de guerra com uma fór- 
mula que deixa clara a relação entre técnica, trauma, violência e o registro de imagens: "A luz do flash do terror cunha/estampa uma impressão fotograficamente exata" ("Das Blitzlicht des Schreckens prägt einen photographisch genauen Abdruck", citado por ASSMANN, 1999: 157 e 247). As imagens do trauma, obsessivamente reiteradas e impossíveis de serem assimiladas, devem ser aproximadas das imagens fotográficas e, com mais razão, das imagens eletrônicas. $\mathrm{O}$ ataque às torres gêmeas de Nova York, em setembro de 2001, foi um exemplo eloquente deste ser traumático das imagens midiáticas. Observando esta relação da imagem fotográfica com a traumática - ambas congelam o tempo, achatam-no em uma bidimensionalidade avessa à simbolização - podemos pensar também na sua capacidade de apontar para o real. À era da fotografia digital corresponde uma concepção da realidade como aquilo que nos escapa: a história como trauma (SELIGMANN-SILVA, 2000). Podemos pensar em uma virada do paradigma da historiografia para o da psicanálise com seus desdobramentos em Ferenczi e Lacan. Trata-se de uma modalidade de descrição da realidade - nascida do esgotamento das grandes narrativas e da violência que marcou o século XX - que privilegia o negativo, o precário, e não a presença positiva e representável. Como índice, escritura de sombra e luz, a foto é um fragmento do mundo e não sua simbolização. Mas o próprio Benjamin apontou para um outro lado deste elemento traumático da técnica de criar imagens. Falando do cinema (que com a montagem incorpora também o choque como princípio estético), ele indicou uma capacidade terapêutica via esta performance que abala. Estes dispositivos nos treinam para a vida pontuada por choques e rupturas. Além disto, com Benjamin também podemos ver tanto o cinema como a fotografia como capazes de abrir aquilo que ele denominou de inconsciente ótico. Este revela novos aspectos insuspeitos de nosso corpo e de nossos gestos. Valorizando a recepção tátil das imagens, que Benjamin retoma de Lucrécio, podemos pensar na capacidade destas de criar esteios para nosso mundo. Ou seja: as imagens técnicas, e de modo mais radical, as imagens eletrônicas, servem tanto de reprodução do abalo e de potenciação do trauma, como também podem servir de 
terapia de choque. Evidentemente cada imagem resolverá esta ambiguidade a seu modo, conforme também o seu modo de recepção.

É verdade que a foto digital mantém uma origem metonímica que ela compartilha com a foto analógica. A fotografia continua a ser fotografia, ou seja, uma inscrição feita pela luz. O princípio da captura do mundo por meio de uma "janela" é mantido. Podemos reescrever, reelaborar à vontade a imagem, mas enquanto falamos de "fotografia digital" ainda mantemos a origem da imagem no recorte de um pedaço do mundo. Mas se a sua relação umbilical com o mundo não é posta em questão, a própria verdade o é. No limite, é a "verdade do mundo" que é posta em suspensão por esta técnica. Ela já apresenta o mundo como digitalizado, como parte de um código binário, e pode multiplicá-lo (ou diminuí-lo) e transformá-lo como o agente da fotografia quiser. E aqui entramos em um outro aspecto essencial desta revolução digital. $\mathrm{O}$ abalo na capacidade de atestação das fotos implica uma transformação na própria figura do fotógrafo e de seu papel na composição das fotografias. Antes a reprodução das fotos permitia uma manipulação qualitativamente e quantitativamente muito inferior à dos atuais softwares. Agora o receptor das fotografias se torna um fotógrafo de segunda ordem. Ele está apenas dispensado da tarefa de capturar a "imagem primária". Sua liberdade de intervenção nas imagens é tão grande que ele também pode ser denominado de agente da fotografia. A figura clássica do fotógrafo morre junto com a fotografia analógica.

Aquele abalo detectado por Benjamin, gerado pelo desenvolvimento das técnicas de reprodução, era para ele o outro lado da crise e da renovação da humanidade. Agora também podemos dizer que a metáfora fotográfica digital representa apenas um aspecto da revolução em nossa visão de mundo. Ela permite visualizar algumas de suas facetas. A própria fotografia digital é apenas um pequeno fato se colocado ao lado da verdadeira revolução por que passamos agora, que é, antes de mais nada, uma revolução no nosso próprio organismo. A possibilidade de manipular imagens é apenas um fenômeno menor se comparado à nossa possibilidade de sintetizar a vida. Vivemos não a era da reprodução técnica, mas sim da síntese técnica não só de imagens, mas também de corpos, de 
organismos. É esta nova virada na "reprodução técnica" (que passa a ser síntese), a virada biológica, que está no centro de nossas sociedades hoje. É desta entronização do biológico que derivarão as próximas mudanças de peso em nossas vidas.

Não podemos deixar de perceber também que a imagem digital ainda abala a temporalidade ligada à fotografia analógica em outro aspecto, para além da superação do tempo da revelação. Benjamin notara que, no que toca à fotografia (analógica), as bases e suportes materiais da foto não tinham mais a importância que possuíam no contexto das artes tradicionais. Em um quadro, num desenho e numa escultura, a base material é desgastada pelo tempo. Daí porque a escultura, para Benjamin, era o exemplo máximo da arte aurática, ou seja, daquela modalidade tradicional da arte que corresponde a um mundo onde o passado se conecta ao presente como tradição. A unidade da pedra que origina a estátua seria uma manifestação da existência de idéias eternas. À fotografia, com a sua reprodutibilidade que lhe é essencial, corresponderia uma sociedade na qual não haveria mais espaço para esta crença em idéias eternas. Mas Benjamin, que não pôde ver a revolução digital, não levou suficientemente em conta nosso verdadeiro culto das fotos antigas. $\mathrm{O}$ desgaste do papel fotográfico e a cor sépia das fotos antigas fazem destas objetos cobiçados, verdadeiros representantes de uma era na qual o tempo ainda podia se inscrever nas bases materiais da fotografia. Se é verdade que o álbum de fotografias, arquivo da memória da família, ainda não está totalmente desbancado, é difícil, por outro lado, imaginar que ele poderá resistir por muito tempo. Hoje vivemos uma fase de transição na qual enviamos nossas fotos para "revelar" (na verdade para imprimir) nas mesmas lojas de fotografia que ainda vendem os últimos rolos de filme analógico. Em breve o armazenamento será totalmente digitalizado. Álbuns eletrônicos (celulares, relógios, e outras telas eletrônicas, além de nossos computadores) substituirão as bases de papel.

Podemos falar de uma desaparição da fotografia. Trata-se de uma desaparição paradoxal, de algo que justamente foi criado para registrar o que potencialmente logo desaparece. A fotografia em papel guardava uma 
presença, uma densidade que foi e é muito explorada pelas artes plásticas. As potencialidades artísticas da fotografia analógica certamente nunca foram tão exploradas antes da fase de sua desaparição. É como se, diante de seu fim, a fotografia analógica se tornasse ainda mais eloquente como uma metáfora ambígua de nossa memória, que é sempre inscrição da presença e de seu apagamento. Decerto já possuímos muitas grandes obras de arte na base digital, mas o princípio da fotografia analógica ainda deverá produzir muitas grandes obras também.

Muitos outros elementos da fotografia tradicional são abalados, em menor ou maior escala, pela foto digital. Por exemplo, a questão dos direitos autorais. Sabemos como este tema já era complicado na era da fotografia analógica. Mas, com o tempo, desenvolveram-se procedimentos de garantia de respeito à autoria das imagens. Com a fotografia digital, que só pode ser compreendida com a paralela abertura do universo da web, esta questão ganhou uma dimensão inaudita. Além da facilidade de manipulação e de multiplicação das imagens, a incrível capacidade de circulação delas acrescenta mais uma dificuldade para se controlar os direitos autorais. $\mathrm{Na}$ era digital a autoridade do fotógrafo é posta em questão. Esta autoridade também é abalada pela fantástica democratização dos aparelhos fotográficos. Todos agora somos fotógrafos, e com isso se indica não apenas que somos agentes da fotografia enquanto manipuladores e agentes na sua circulação: todos atuamos na própria captação das imagens. Uma criança de cinco anos já possui hoje sua primeira câmara digital. Além disso, a câmara digital, na medida em que nos possibilita um acesso imediato às imagens capturadas e como não depende de sua tradução para um meio duro, propicia uma multiplicação do próprio ato de captura de imagens. É uma banalidade afirmar que fotografamos muito mais na era digital. Se esta multiplicação quantitativa significa uma elevação qualitativa é uma questão ainda a ser respondida, de qualquer modo estas fotografias, mais e mais assumem o caráter de pós-fotografias: são inscrições imagéticas eletrônicas de outra qualidade que ainda não sabemos exatamente como definir. A multiplicação quantitativa de imagens pode ser explicada não só pela facilidade técnica, 
mas também por uma necessidade quase que patológica do indivíduo contemporâneo de registrar tudo em imagens. "Glorifier le culte des images (ma grande, mon unique, ma primitive passion)”, escreveu Baudelaire. Estas palavras caracterizam também o indivíduo contemporâneo com sua sede de construir uma casa em um mundo onde tudo se liquefaz. Como suas imagens também são líquidas, ele não pára de inscrevêlas. Nossa era de museus e arquivos é uma filha de nosso descolamento da tradição e, mais recentemente, de nossa crise quanto aos limites do próprio humano.

\section{A ARTE DA DESAPARIÇÃO E DO RENASCIMENTO}

O texto que acabo de apresentar aqui, com poucas mudanças, acompanhou o catálogo da exposição $A$ última foto de Rosângela Rennó, na Galeria Vermelho em São Paulo em 2006. Esta artista é uma das que consegue, hoje, levar mais adiante o trabalho com a fotografia como uma reflexão sobre a memória, o desaparecimento e a própria questão - para mim fundamental - da relação entre as imagens fotográficas e a violência. As obras de Rosângela Rennó podem ser vistas e lidas dentro da antiquíssima tradição da reflexão sobre a memória como uma inscrição. Dentre os textos mais importantes desta tradição destaca-se uma conhecida passagem de Aristóteles. Nela, o filósofo nos dá elementos para pensar a atual diluição das bases de nossa memória cultural. Ele descreve nosso aparelho anímico como um dispositivo onde as mensagens se inscrevem com maior ou menor durabilidade, conforme a sua constituição. Para ele, cada pessoa possuiria uma determinada consistência de superfície mnemônica, que ele aproximou da noção antiga de "bloco de cera” (a metáfora por excelência para a memória na Antiguidade), o que determina a sua capacidade de reter mais ou menos informações:

(...) em certas pessoas devido à incapacidade ou idade, a memória não se dá mesmo sob um forte estímulo, como se o estímulo ou selo fosse aplicado à água que corre; enquanto em outras, devido ao desgaste, como em paredes antigas de prédios, ou à dureza da superfície de apoio, a impressão 
não penetra. Daí os muito novos e os muito velhos terem memória fraca; eles estão no estado de fluxo: o jovem devido ao seu crescimento, o idoso, devido à sua decadência. Pelo mesmo motivo, nem o muito veloz, nem o muito vagaroso parece ter boa memória, os primeiros são mais úmidos do que deveriam ser e os últimos mais duros; nos primeiros a imagem não permanece na alma, e nos últimos ela não deixa nenhuma impressão (ARISTÓTELES, 1995: 450b 1-10).

Nossa era está em "estado de fluxo" e é marcada pela velocidade da circulação. Rosangela Rennó constrói dispositivos que nos ajudam a refletir sobre esta nossa condição paradoxal de submersos em imagens e ao mesmo tempo de amnésicos. No seu catálogo $O$ arquivo universal e outros arquivos encontramos várias obras com base fotográfica que representam muito bem esta pesquisa artística em torno do estatuto das imagens. Limito-me a destacar alguns exemplos.

A série "Parede cega" (1998-2000) agrupa várias molduras, que lembram molduras fotográficas tradicionais, só que sem imagem alguma. O título parede-cega - uma parede sem abertura - remete à idéia de que a fotografia emoldurada na parede pode ser vista como uma janela no espaço-tempo. As molduras são apresentadas como que afundadas na parede, como se elas tivessem sido viradas de costas. Na verdade, tratase de fotografias doadas ou adquiridas em feiras de artigos de segunda mão (RENNÓ, 2003: 62), que foram pintadas e colocadas sobre painéis de espuma e lycra e fotografadas por Vicente de Mello. Mas podemos também interpretar estas fotos pintadas de cinza como espelhinhos cegos: uma superfície de inscrição mais próxima a da superfície da água que corre, mencionada na passagem acima de Aristóteles. A cor da obra remete à cor de um negativo fotográfico. Tudo é cego nesta obra que revela - com o perdão do jogo de palavras - o ponto cego da nossa visão fotográfica. Ao olharmos esta série vemos apenas a falta, a desaparição, sem seu avesso de presença, sem o enfático "isto foi - isto é" que toda fotografia parece dizer. Vemos apenas o "isto não é”, ou pensando em termos de uma economia sublime, de uma estética do 
silêncio e da falta para indicar o irrepresentável - assistimos nesta obra simplesmente ao "Isto é" ou o "How is it" becketiano. Vemos a imagem como pura performance, sem o lastro da referencialidade. Trata-se do dispositivo fotográfico de apresentação

\section{Figura 1}

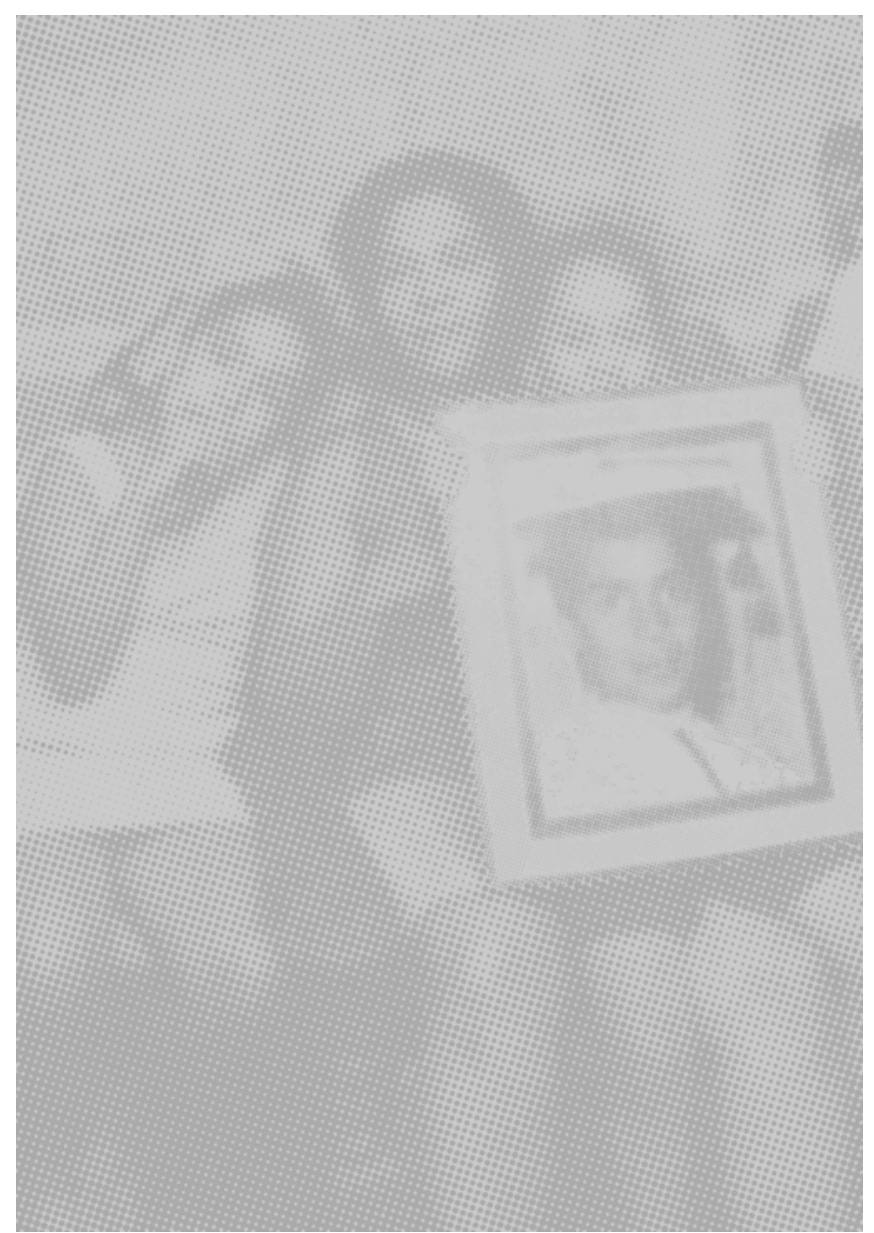

Rosangela Rennó “Corpos da alma II” (1990-2003) (Foto: MarceloCarnaval_Agência O Globo) cegado e que remete a uma espécie de cegueira que também constitui a recepção da fotografia. Podemos pensar, assim, que a moldura da foto é esta própria cegueira, uma falta e um desejo que quer se saciar na inscrição de luz - que neste caso não acontece na sua totalidade. Encontramos apenas molduras vazias. Suportes à espera de um olhar.

No mesmo catálogo, a série "Corpos da alma II” (1990-2003), um conjunto de fotografias de jornal mexidas digitalmente, trabalha com fotografias dentro de fotografias. Pessoas carregam fotos em passeatas ou em ambientes familiares. [FIG. 1] As pessoas que se transformam em porta-retratos são apresentadas em imagens ampliadas de tal modo que parecem fotos de jornal com seus pontos fotográficos super-dimensionados. Aqui é a foto-presença, a foto-corpo, que está em jogo. A fotografia é apresentada como um Ersatz das pessoas, sejam elas líderes políticos ou parentes desaparecidos. A fotografia se apresenta aqui como testemunho: de uma fé política, ou testemunho jurídico, ou ainda, testemunho dos fatos, tal como costumamos ver as fotos dos jornais. As fotos de fotos servem para apresentar a fotografia como um dispositivo capaz de incorporar outras imagens. Trata-se de uma metaimagem, imagem da imagem que aponta para as imagens como criação e 
construção do mundo, no mesmo gesto em que, paradoxalmente, apresentam as imagens como foto-corpo, imagens-pessoas. quase que de carne e osso.

Já na série "Vaidade e violência" (2000-2003) vemos textos emoldurados e escritos em preto sobre o preto - como em Ad Reinhardt, o pintor expressionista abstrato, criador de obras black-on-black, como vemos na sua série Abstract Painting, dos anos 1960, que figura linhas pintadas em preto, sobre um fundo preto. O título da série é uma irônica (auto-)referência à relação entre imagem, escrita, arte e violência. Nesta série de Rennó o texto que faz as vezes de foto, refere-se a fotografias. No primeiro quadro o texto diz:

A imagem que ela diz guardar de seu algoz é a de um homem que confundia seus interlocutores quando assumia o comportamento frio, decidido e muito objetivo nos interrogatórios. Vinte anos depois, E.M., 41 anos, ex-militante do MR-8, ficou trêmula ao ver a fotografia recente do delegado D.P. e não teve dúvida em afirmar: "É ele mesmo! Essa fisionomia ficou muito forte para mim (RENNÓ, 2003).

A cena retratada por Rennó é a cena de um reconhecimento ao mesmo tempo trágico e jurídico. Nesta cena, a imagem mental encontra uma imagem fotográfica e provoca uma reação parecida com a que temos diante de pessoas. Trata-se aqui de uma imagem-pessoa ou imagemcorpo, de um torturador, que estava inscrita na memória da enunciadora e foi reconhecida na imagem fotográfica. Mas na obra e Rennó, a única imagem que vemos é a de palavras em preto em uma moldura e fundos pretos, que para serem lidas exigem o constante deslocamento do leitor para conseguir extrair o texto da página negra que brilha. Rennó fornece apenas as iniciais da torturada e do algoz, transformando este reencontro em uma espécie de evento coletivo, que marcou um país, o Brasil, já que o MR-8 é explicitamente mencionado. Esta obra é um dispositivo que permite pensar as imagens fotográficas como inscrições que devem ser lidas, ao mesmo tempo que aponta para o ser imagem da escrita. 
Toda imagem tem algo verbal, simbólico, que pode ser interpretado e traduzido - de "n" maneiras - pelo receptor, mas toda imagem tem também restos não-verbalizáveis. As imagens são ao mesmo tempo verbais e mudas. Assim como existem ausências de palavras diante de certas

\section{Figura 2}

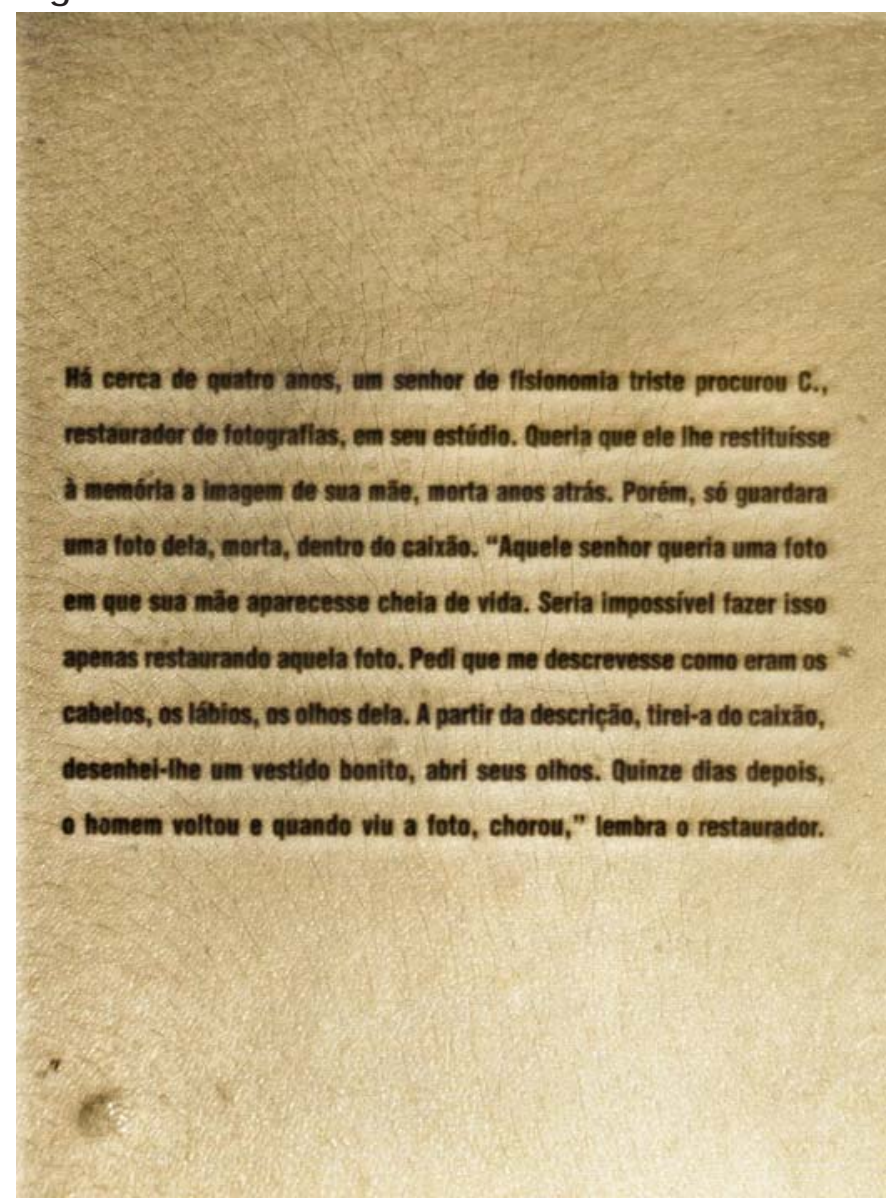

Rosangela Rennó "Cicatriz" (1996-2003) imagens, existem também cenas que deixaram imagens - embaçadas, traumáticas - apenas na mente de certas pessoas. A ausência de imagens das torturas é parte do buraco negro de nossa memória da violência da ditadura. A violência dos atos brutais do terrorismo de Estado acontecia ao mesmo tempo que a tentativa de se apagar os seus rastros. Havia um tabu da imagem em torno das câmaras de tortura. Também a impossibilidade de testemunhar aquela cena que se passou na câmara obscura está indicada nesta impressionante obra.

Por último, destaco uma obra da série "Cicatriz", (1996-2003) do mesmo catálogo. Nesta série vemos a cada página, alternadamente, fotos de fragmentos de corpos com suas tatuagens extraídas de negativos fotográficos do Museu Penitenciário Paulista - e fotos de fragmentos de peles recobertas com inscrições, como se estas tivessem sido realizadas sobre a pele, queimando-a. Os textos, como na série "Vaidade e violência", também dizem respeito a fotografias. No exemplo que apresento [FIG. 2] o texto diz:

Há cerca de quatro anos, um senhor de fisionomia triste procurou C., restaurador de fotografias, em seu estúdio. Queria que ele lhe restituísse à memória a imagem de sua mãe, morta anos atrás. 
Porém, só guardara uma foto dela, morta, dentro do caixão. 'Aquele senhor queria uma foto em que sua mãe aparecesse cheia de vida. Seria impossível fazer isso apenas restaurando aquela foto. Pedi que me descrevesse como eram os cabelos, os lábios, os olhos dela. A partir da descrição, tirei-a do caixão, desenhei-lhe um vestido bonito, abri seus olhos. Quinze dias depois, o homem voltou e quando viu a foto, chorou', lembra o restaurador (RENNÓ 2003).

O texto inscrito sobre a pele-pergaminho é uma pequena e contundente narrativa. Nela a presença da fala em primeira pessoa, na voz do restaurador, torna tudo mais imagético e intenso. O texto é apresentado como um ato de memória, ele se fecha com a expressão "lembra o restaurador". Todo texto é registrado na pele, como uma cicatriz, metáfora potente da memória traumática. A narrativa da ressurreição da mãe via fotografia remete à força vital da imagem fotográfica: se na série "Corpos da alma II" as fotos representavam pessoas desaparecidas que continuavam a viver apenas nas fotos, aqui vemos mais do que a sobre-vida, vemos o próprio renascer via restauração fotográfica. O fotógrafo proclama: "abri seus olhos". Esta imagem abala e faz chorar, tanto quanto as imagens de desaparecidos que sabemos que não poderão mais ser renascidos. Esta mãe que ganha vida pela intervenção do fotográfo-artista-deus remete novamente a esta força presencial da imagem fotográfica: ela é quase tão forte e intensa quanto as imagens reais de pessoas. Daí desde o século XIX se falar na capacidade como que espectral da fotografia de captar fantasmas e pessoas ausentes. Neste trabalho vemos várias metamorfoses: a mãe que morrera e fora transformada em imagem fotográfica que depois, por meio desta foto e da descrição - ekphrástica - que o filho faz dela, volta a ter vida graças à intervenção do restaurador, este artesão que lida com o desgaste do tempo. Mais do que nunca, nesta imagem da mãe ressuscitada vemos uma indicação da força vital da imagem fotográfica, com sua capacidade de nos abrigar, como em um útero analógico ou eletrônico. A bidimensionalidade da imagem fotográfica 
2 - Neste sentido podemos lembrar que no momento vemos nos Estados Unidos a difusão de flat-daddies e flatmummies que são encomendados pelos familiares de soldados que estão no Iraque e em outras missões patrióticas, para reduzir os efeitos da ausência destes pais e mães. Estes pais e mães de papel têm como função produzir uma proximidade àquilo que está distante. Trata-se de uma arte da memória esvaziada da força política que encontramos nas fotos da América Latina... Outros contextos, outros jogos imagéticos e trágico-

compassivos. não rouba dela esta sua fantástica força presencial. [2] As fotos de forte teor indicial e icônico, com caráter de foto-presença, de certa forma revertem a função aurática benjaminiana, uma vez que Benjamin via na aura "uma teia singular, composta de elementos espaciais e temporais: a aparição única de uma coisa distante, por mais próxima que ela esteja" (1985: 101). O próprio Benjamin viu que a fotografia - como arte pósaurática - tinha justamente a capacidade de aproximar coisas do indivíduo, distantes no tempo e no espaço (1985: 168). Nela se unem transitoriedade e repetibilidade: como nas imagens do trauma a que me referi neste trabalho.

\section{FOTOGRAFIA E SOBRE-VIDA}

Benjamin enfatiza também em seu texto sobre a obra de arte na era da sua reprodutibilidade técnica que o rosto humano teria sido o último lugar de resistência do valor de culto das imagens que, com o abalo da reprodução técnica, teria migrado para o valor de exposição das imagens. "O refúgio derradeiro do valor de culto foi o culto da saudade, consagrada aos amores ausentes ou defuntos. A aura acena pela última vez na expressão fugaz de um rosto, nas antigas fotos” (1985: 174). As fotos dos desaparecidos na América Latina emanam esta aura. Uma das fontes da incrível melancolia que estas fotos transmitem é um intenso desejo de presença. Por outro lado, elas são filhas de uma era pós-aurática. Disto resulta uma série de peculiaridades. Benjamin valoriza as imagens que o fotógrafo Atget fazia de Paris, justamente porque ele fotografou aquela cidade esvaziada de seus habitantes e transeuntes. Escreveu-se que Atget fotografou as ruas de Paris "como quem fotografa o local de um crime. Também este local é deserto", comenta Benjamin. "É fotografado por causa dos índices que ele contém. Com Atget, as fotos se transformam em autos no processo da história" (1985: 174). Benjamin via aí a "significação política latente" da obra daquele fotógrafo. As fotos necessitam agora de legendas para serem entendidas (Cf. 1985: 129). Ou seja, com Atget as fotos se transformam em verdadeiros jogos de emblema, onde interagem a imagem e a inscrição, uma re-significando a outra: uma suplementando a outra. A insuficiência de uma tentando ser superada pela outra. Os textos nomeiam as imagens e estas dão corpo aos nomes. 
Se para Benjamin, "escrever história significa dar fisionomia às datas", aqui trata-se de dar corpo e nomes a imagens-datas. Nas fotos de desaparecidos vemos, portanto, o encontro da melancolia aurática dos retratos com a função jurídica da foto de tribunal: a foto-prova (pós-)aurática. Vale lembrar também que Atget fotografou uma Paris a qual, como escreveu Baudelaire no seu poema Le Cygne, "Muda mais rápido, infelizmente!, que o coração de um mortal". Se Benjamin constatou que "aquilo que está para desaparecer assume a forma de uma imagem”, nas fotografias das ruas de Paris de Atget reconhecemos uma total consciência deste fato. No verso das suas fotografias o fotógrafo anotava: "Vai desaparecer".

A sobre-vida fotográfica dos desaparecidos nas ditaduras civil-militares na América latina tem um sentido que não tem nada a ver com o aparente milagre do sudário: muito pelo contrário, estas fotos estão diretamente ligadas ao que Benjamin chamou de uma nova significação política da fotografia. As fotos de identificação, criadas no final do século XIX para controlar as populações, foram transformadas na América Latina em poderosas fontes documentais para comprovar a existência dos desaparecidos. Foram estas fotos, ao lado das extraídas dos álbuns de família, que, ampliadas, puderam ser anexadas aos laudos apresentados ainda durante as ditaduras, exigindo do Estado a restituição dos corpos o habeas corpus que havia sido suspendido no estado de exceção que imperou em muitos países da América Latina dos anos 1970 e 1980.

Como escreveu Carmen Hertz,

No Chile, esta prática de desaparição forçada de pessoas foi implementada a partir do 11 de setembro de 1973, como método de dominação da sociedade civil e principalmente dos oponentes ideológicos do regime de fato (2000: 48).

Nos anos seguintes esta prática foi mantida. A Dirección de Inteligencia Nacional (DINA), que estava diretamente dependente do chefe da junta do governo militar, Augusto Pinochet, fora criada por decreto-lei e tinha como objetivo levar a cabo esta repressão política. Suas operações se estenderam não só por todo território chileno, mas 
também, por meio da operação Condor, a outros países ditatoriais aliados: Argentina, Uruguai, Paraguai e Brasil (HERTZ, 2000: 49s.). A fotografia teve um papel decisivo, neste quadro, enquanto meio de resistência e oposição à ditadura. Os trabalhos de Rosângea Rennó, fortemente calcados no dispositivo fotográfico, foram criados com uma distância de cerca de 10 anos do final da ditadura civil-militar brasileira (1964-1985), já estas fotografias a que me refiro agora foram parte da própria ação de resistência dentro do período do "estado de exceção" da ditadura chilena.

O estudo da relação entre fotografia e ditaduras na América Latina deve levar em conta estes dois momentos aos quais se ligam duas abordagens do dispositivo fotográfico e das fotos: na ditadura as fotos têm um papel de denúncia. São um testemunho no sentido jurídico de testis. o fotógrafo (e o público que contempla as imagens) são como que o "terceiro" dentro de uma contenda entre dois partidos. Evidentemente esta modalidade jurídica do uso fotográfico se estende depois das ditaduras, tanto nos processos jurídicos como também em trabalhos historiográficos. Já a apropriação destas imagens depois das ditaduras está subordinada a um trabalho - sempre conflitivo, político - de memória. No embate entre a continuidade do negacionismo - que normalmente se valeu de leis de Anistia, como a do Chile de 1978 e a do Brasil do ano seguinte - e, por outro lado, aqueles que lutam pela justiça e, portanto, por manter acesa uma memória do mal cometido, estabelece-se também um conflito entre iconoclastas e defensores das imagens. Existe uma guerra de arquivos, que muitas vezes foram queimados ou escondidos e se transformam em verdadeiros fantasmas, espectros nos quais se projeta uma capacidade de redimir o mal: coisa que, sabemos, mesmo no caso em que acontecem julgamentos e até condenações, como na Argentina, no Uruguai e no Chile (mas não no Brasil), é impossível. O negacionismo dos algozes e de seus cúmplices e sucedâneos é um fator de primeira ordem para considerarmos estas imagens fotográficas: normalmente o negacionismo vai ao encontro dos assim chamados interesses de Estado, que visa promover a "conciliação nacional”. Estas imagens são, portanto, imagens malgré tout, para utilizar a expressão de Didi-Huberman: apesar do negacionismo e apesar também das próprias limitações do testemunho. Pois as fotos eram em grande 
parte proibidas nas ditaduras, via censura ou até mesmo via decretos que proibiram a fotografia em público na Argentina e, no Chile, a sua publicação em revistas. $\mathrm{Na}$ ocasião os editores de oposição chilenos tiveram que apelar para letras para construir as imagens em suas publicações. Nestas páginas vemos o ser-escritural das imagens e sua relação com a censura em embate com Eros: o desejo de vida. Já os fotógrafos reagiam portando suas fotos ampliadas, como homens-sanduíche, pelas ruas do centro de Santiago. As fotos são aqui verdadeiros agentes da oposição. Por falta de espaço terei que me restringir a um exemplo aqui.

Um caso paradigmático neste contexto é o do fotógrafo chileno Luis Navarro. De Antofagasta e sendo perseguido após o golpe de 1973, ele acabou indo para Santiago no final de 1974. Lá ele começa a trabalhar na Vicaría de la Solidariedad. Nesta posição ele foi responsável pelas fotografias do importante caso Lonquén, o primeiro sítio clandestino descoberto com cadáveres de desaparecidos em 1979. Nas comemorações do Tedeum na Catedral de Santiago, feito para comemorar em 11 de março de 1981 a proclamação da nova constituição, Navarro foi preso e posteriormente torturado. Graças à intervenção do Cardeal Raúl Silva Henríquez e de organizações internacionais, ele foi libertado. Esta prisão, como destaca o historiador da fotografia chileno Gonzalo Leiva Quijada (2004 e 2008), serviu de impulso para a fundação da AFI: a Asociación de Fotógrafos Independientes. Esta organização teve um papel fundamental durante a ditadura chilena, apoiando o trabalho de importantes fotógrafos, dando credenciais a eles e os defendendo dos ataques das forças do governo. Além do próprio Navarro, participaram da AFI fotógrafos como Paz Errázuriz, José Moreno, Hellen Hugues, Rodrigo Casanova, Álvaro Hoppe, Cláudio Bertoni, Jorge Ianiszewski, Leonora Vicuña, Kena Lorenzini e Rodrigo Rojas (assassinado pelos membros da ditadura em 1986, quando tinha apenas 19 anos, de modo bárbaro, queimado vivo ao lado da jornalista Carmen Gloria Quintana).

Luis Navarro é um dos responsáveis pela introdução das fotos ampliadas de carteiras de identidade e de fotos de família: estas imagens não apenas serviram, como vimos, para dar início aos processos contra a ditadura, mas também foram parte integrante das ações dos familiares e amigos dos desaparecidos. Gonzalo Leiva considera estas fotos o maior fato na história da 
fotografia no Chile desde seu início no país em 1840 (2004: 15).

Nas manifestações no final dos anos 1970 os familiares portavam estas ampliações de fotos [FIG.3] . A demanda dos corpos se fazia com

\section{Figura 3}

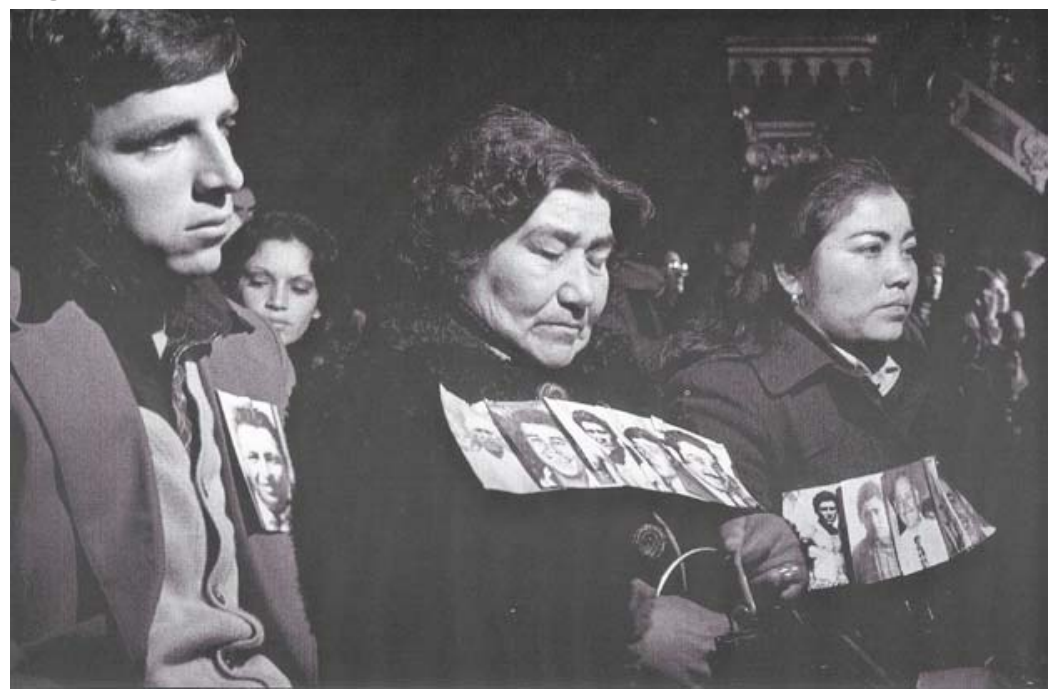

Luis Navarro. Missa por Lonquén. 1979

\section{Figura 4}

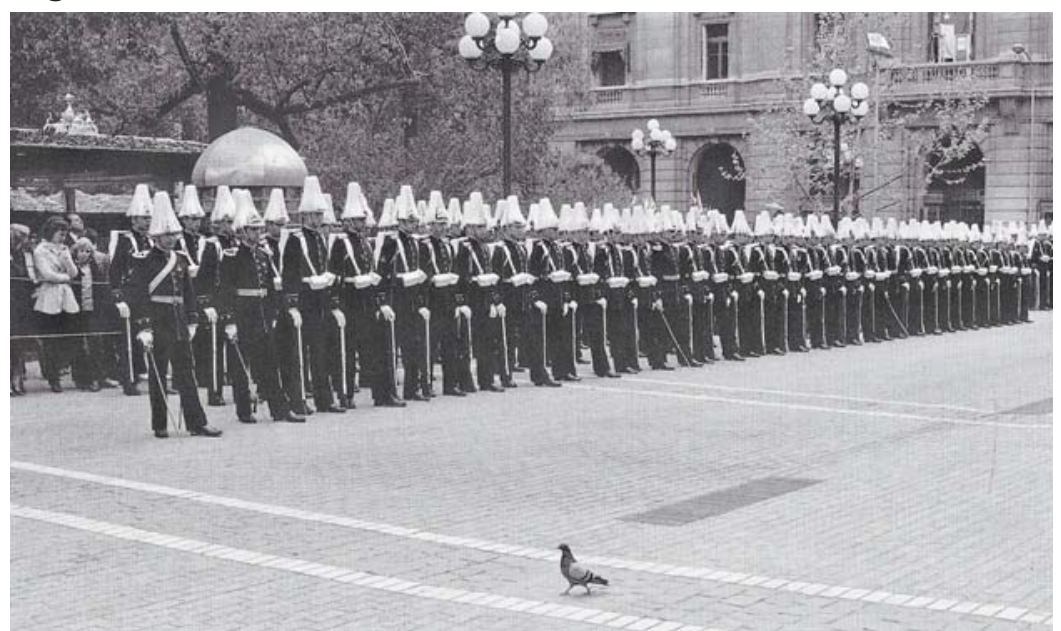

Luis Navarro. Te Deum. 1980 aquelas imagens-testemunho. Navarro também fotografou outras vítimas do governo autoritário, os marginalizados economicamente, assim como captou a vida cotidiana em fotos com forte marca autoral, como notou Leiva Quijada. Sua fotografia de seu pai, reagindo à narrativa de sua prisão, quando leva uma das mãos diante dos olhos, tem uma rara força narrativa. Suas fotografias da mise em scène do poder também são importantes e apontam para uma característica das fotografias sob ditaduras: o fotógrafo muitas vezes tenta capturar imagens da esfera do poder, que, na mesma medida em que documentam, permitem construir alegorias e narrativas críticas. Assim a foto de um Tedeum em 1980 [FIG. 4] capta com certa ironia a pompa e austeridade militar sendo como que desprezada por um pombo que caminha exatamente em meio a uma trilha que vai na direção oposta para onde se voltam os militares. O tempo frutífero, típico das imagens sem movimento, assume no foto-jornalismo um significado muito mais radical. Aqui o disparo do 
obturador pode significar também um tiro certeiro no poder.

É importante concluir de modo anticlimático, para evitar apelos emotivos fáceis diante de uma temática tão carregada de emoções, injustiças e desilusões. Volto então rapidamente para as observações iniciais sobre a fotografia. Como vimos, as escritas de luz e sombra das fotos ganharam novo significado na era das imagens técnicas eletrônicas. Uma foto de Luis Weinstein, também da AFI, da fotografia engolindo outra fotografia [FIG. 5] aponta para esta situação. A bidimensionalidade das fotos como trauma, podem adquirir volume e vida, conforme a sua recepção e reinserção em um novo contexto. De certa maneira é este volume quase narrativo que os artistas que trabalham com as fotografias visam, ou mesmo os chamados autores de anti-monumentos, como Horst Hoheisel, Jochen Gerz, entre outros. Mas nossa sociedade está se tornando cada vez mais imagem da imagem e o dispositivo fotográfico eletrônico está como que canibalizando a própria memória, à qual ele antes estava subordinado. Nosso corpo, para Freud e a psicanálise, uma extensão de nossa memória e do inconsciente, está se tornando matéria plástica, sem possibilidade de inscrição do tem-

\section{Figura 5}

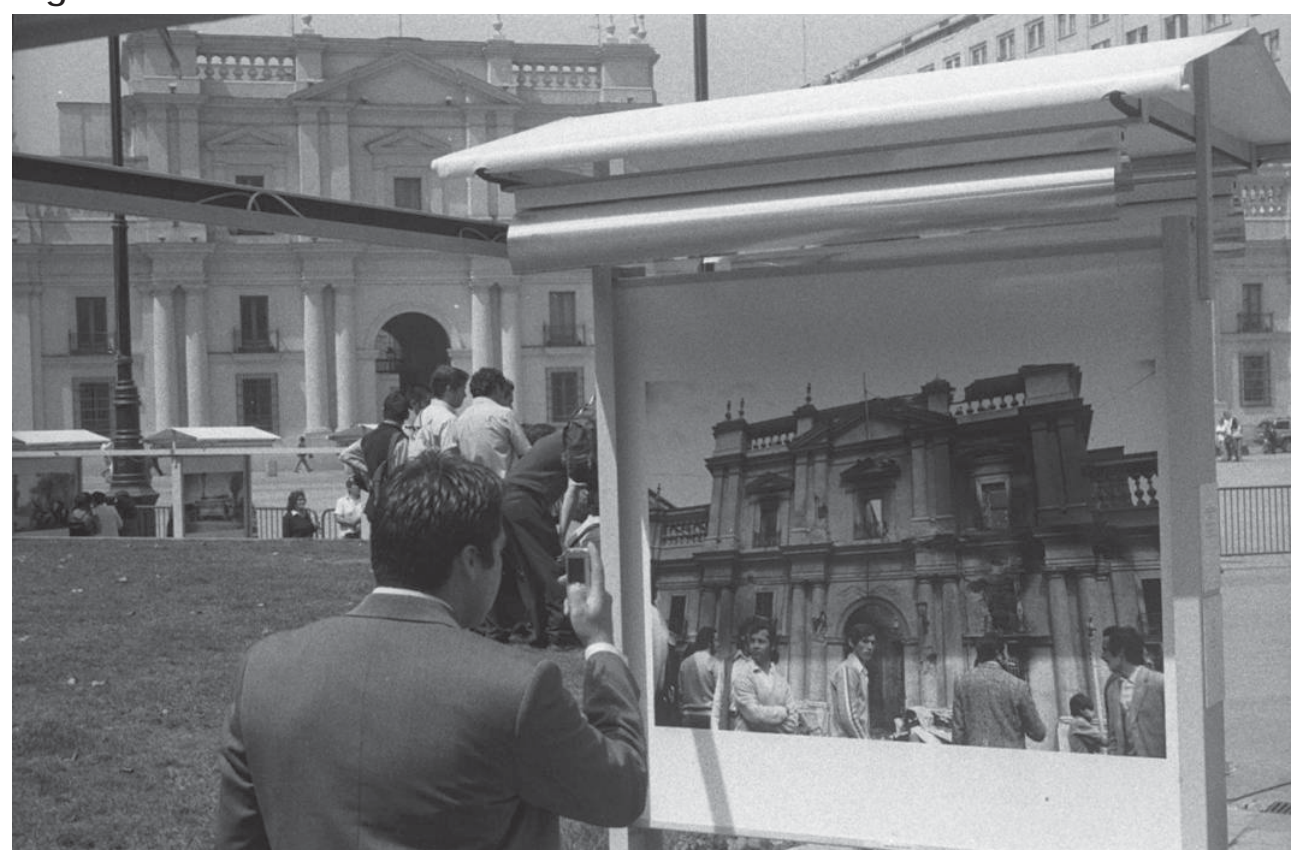

Luis Weinstein. Exposición fot. "Chile en 100 miradas", foto de Antonio Larrea fotografiada por un ciudadano. Chile 10/2005 
po, assim como nossas memórias se aproximam e são deglutidas pelas de nossos computadores. A novidade é que aquilo que sempre pareceu impossível, a arte do esquecimento, é a grande promessa de nosso presente. $\mathrm{O}$ dispositivo fotográfico é assim consumido pelo teor traumático que sempre trouxe consigo. Mas Benjamin - admirador de Baudelaire, a quem ele chamou de traumatófilo - vislumbrou na capacidade de esquecer um ganho em Spiel-Raum, em espaço de jogo, de liberdade. Na América Latina vivemos o impasse de habitarmos ao mesmo tempo a modernidade técnica analógica, com seu desejo de memória, e a era das imagens eletrônicas, com seu desejo de pós-história. Com Borges - um dos maiores especialistas de todos os tempos no que tange às imagens mentais - ainda insistimos em dizer: "Só uma coisa não existe: o esquecimento" Os desaparecidos deste continente nos ensinam a não sucumbir ao esquecimento, seja ele o dito esquecimento feliz ou simplesmente o oportunista.

\section{REFERÊNCIAS BIBLIOGRÁFICAS:}

ARISTÓTELES. De Memoria et Reminiscentia. W.S. Hett (transl.). Cambridge: Loeb Classical Library, 1995.

ASSMANN, Aleida. Erinnerungsräume. Formen und Wandlungen des kulturellen Gedächtnisses. München: C.H. Beck, 1999.

BENJAMIN, W. Obras Escolhidas, v. I, Magia e Técnica, Arte e Política. S.P. Rouanet (trad.). São Paulo: Brasiliense, 1985.

DIDI-HUBERMAN, G. et. al. Alfredo Jaar: La Politica de las Imágenes. Santiago: Metales Pesados, 2008.

DUBOIS, P. O Ato Fotográfico e Outros Ensaios. Marina Appenzeller (trad.). Campinas: Papirus, 1993.

HERTZ, C. "Desaparición forzada de personas: método de terror y exterminio permanente.” In: Políticas y Estéticas de la Memoria. Org. por Nelly Richard. Santiago: Editorial Cuarto Proprio, 2000.

LEIVA QUIJADA, G. Luis Navarro. La Potencia de la Memoria. Santiago de Chile: Imprenta Edición, 2004. . Multitudes en Sombras, AFI. Santiago: Ocho Libros Editores, 2008.

RENNÓ, R. Rosângela Rennó: O Arquivo Universal e Outros Arquivos. 
São Paulo: Cosac Naify, 2003.

SELIGMANN-SILVA, M. "História como Trauma", in: M. SeligmannSilva e A. Nestrovski (org.) Catástrofe e Representação, São Paulo: Escuta, 2000. Pp. 73-98.

SELIGMANN-SILVA, M. "A arte de dar face às datas: A topografia da memória na arte contemporânea.” In: Horst Hoheisel, Marcelo Brodsky, Andreas Knitz e Fulvia Molina (orgs.). A Alma dos Edifícios. S. Paulo: Imprensa Oficial do Estado de S. Paulo, 2004. 